\title{
Host relations and DNA reveal a cryptic gall crab species (Crustacea: Decapoda: Crypto- chiridae) associated with mushroom corals (Scleractinia: Fungiidae)
}

\author{
Sancia E.T. van der Meij ${ }^{1,2}$ \\ ${ }^{1}$ Department of Marine Zoology, Naturalis Biodiversity Center, Darwinweg 2, 2333 CR Leiden, The Netherlands \\ ${ }^{2}$ E-mail: sancia.vandermeij@naturalis.nl
}

Key words: cryptic species, Fungicola, host specificity, Indo-West Pacific region, Tropical Eastern Pacific region, Scleractinia

\begin{abstract}
Mushroom corals of the Indo-West Pacific Fungiidae (Scleractinia) provide habitats for a rich associated fauna, including three species of gall crabs (Cryptochiridae). During the course of the present study gall crabs were sampled from many different fungiid hosts. Based on this 'reversed' approach - by studying coral symbionts from a host perspective - a previously unnoticed host specificity pattern was detected. The sampling of gall crab fauna per host coral combined with molecular analyses of $\mathrm{H} 3$ nDNA, 16S and COI mtDNA revealed a cryptic gall crab species closely related to Fungicola fagei. This new species, described hereafter as Fungicola syzygia sp. nov., is predominantly associated with the mushroom coral genera Cycloseris and Pleuractis, whereas its sibling species $F$. fagei is only known to be associated with the host genera Podabacia and Sandalolitha. Based on morphology $F$. syzygia sp. nov. is difficult to distinguish from $F$. fagei, but there are subtle differences in carapace shape, the lateral carapace margins, the border between the orbital angles and the merus of the third maxilliped, as well as in the carapace length/width ratio. The type material of $F$. utinomi and $F$. fagei is figured for comparison.
\end{abstract}

\section{Contents}

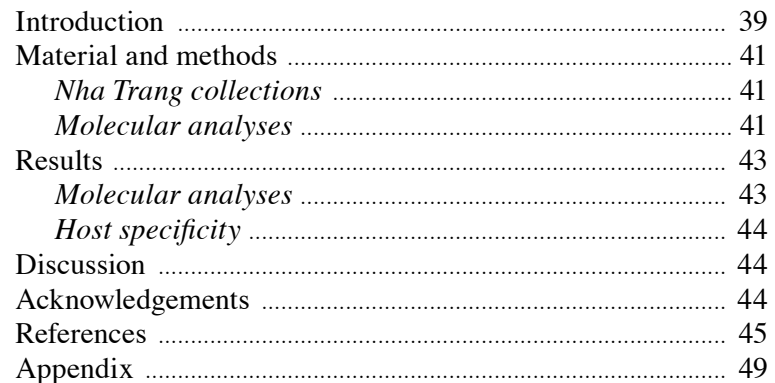

\section{Introduction}

The mushroom coral family Fungiidae occurs in the Indo-West Pacific and tropical Eastern Pacific regions with a distribution ranging from the Red Sea and eastern Africa to the west coast of Central America (Hoeksema, 1989). Several species have been recorded in association with these fungiids (Hoeksema et al., 2012). Most of the associated fauna consists of crustaceans and molluscs, but fishes have also been recorded to live in symbiosis with fungiids (Bos, 2012; Hoeksema et al., 2012). Such heterospecific associations between a host and an associated organism can range from brief facultative encounters to lifelong obligate partnerships (Castro, 1988). Studies on the associated fauna of stony corals are often studied from a symbiont perspective. A 'reversed approach' aims to study associated fauna from the perspective of the host, by collecting specimens from as many host coral species as possible. This reversed approach has previously been applied to several endolithic and epibiotic mollusc taxa obligately associated with fungiids, resulting in the discovery of several cryptic, adaptive radiations (Hoeksema and Kleemann, 2001; Kleemann and Hoeksema, 2002; Gittenberger and Gittenberger, 2005, 2010).

The reversed approach in the examination of a complete inventory of associated fauna was also used in the present study on fungiid associated gall crabs (Cryptochiridae). Gall crabs are obligate symbionts of scleractinians and reside in dwellings in their host coral. They occur worldwide but are most diverse in the Indo-West Pacific region (Fize and Serène, 1957; Kropp, 1990). Three gall crab species, Fungicola fagei (Fize and Serène, 1956), F. utinomi (Fize and Serène, 1956) and Dacryomaia sp., have so far been recorded from 32 mushroom corals (Fize and Serène, 1957; Takeda and Tamura, 1979; Kropp, 1990; Hoeksema et al., 2012; van der Meij and Hoeksema, 2013). The reversed approach for studying gall crab associations already yielded new coral hosts (Hoeksema et al., 2012; van der Meij and Hoeksema, 2013; van der Meij, 2014). Based on host relations and molecular analyses, a cryptic species 


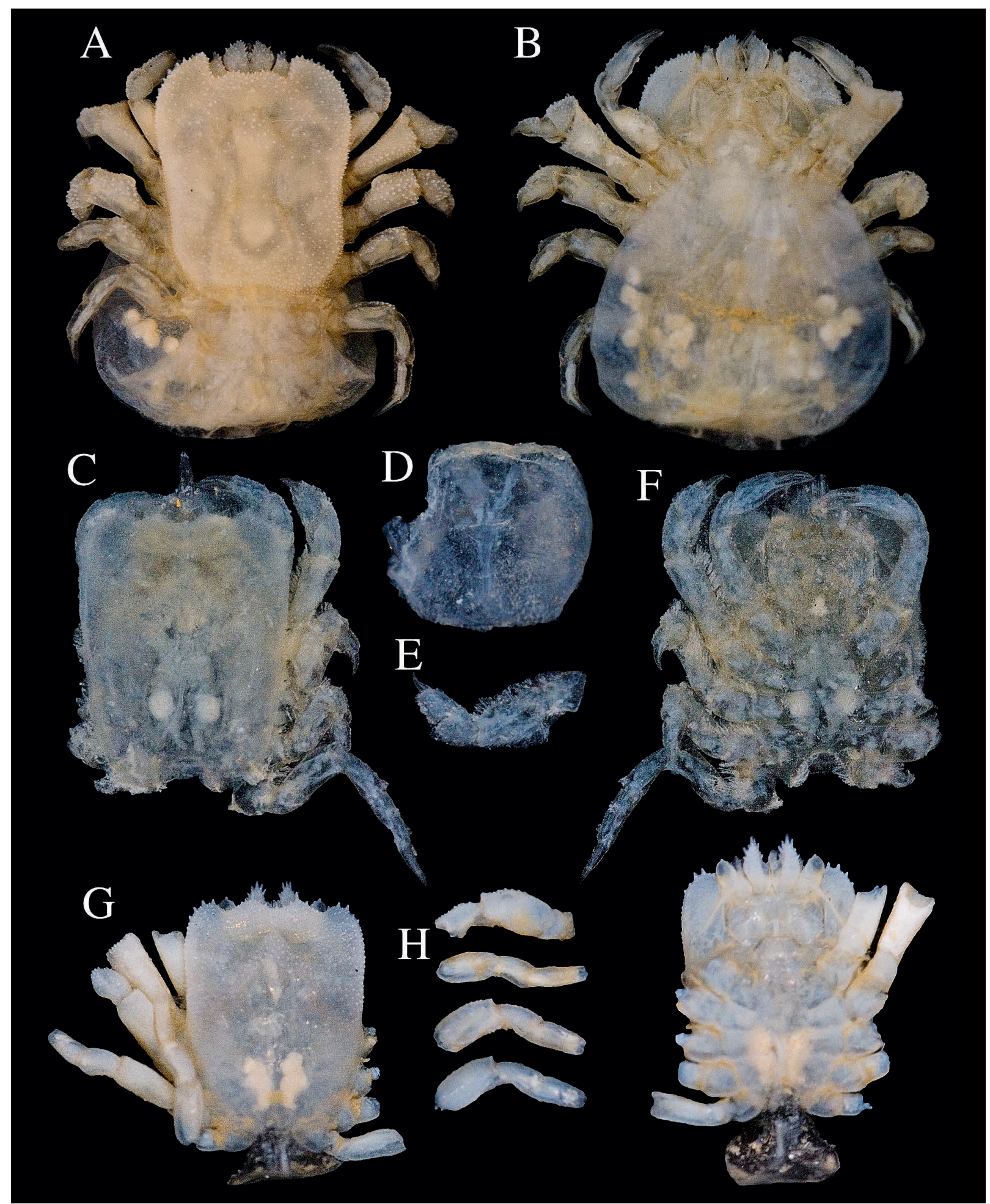

Fig. 1. Types in the Nha Trang collections; A) dorsal view and B) ventral view of the female holotype of Troglocarcinus fagei Fize and Serène, 1956 (E.38.444), carapace $4.5 \times 4.0 \mathrm{~mm}$; C) dorsal view, D) marsupium, E) pereiopod and F) ventral view of the female holotype of T. utinomi Fize and Serène, 1956 (E.37.277), carapace $5.0 \times 4.0 \mathrm{~mm}$; G) dorsal view, H) pereiopods and I) ventral view of the male allotype of T. utinomi Fize and Serène, 1956 (E.37.766), carapace $4.0 \times 3.0 \mathrm{~mm}$. Photos by SET van der Meij and BT Reijnen. 
closely related to $F$.fagei was discovered (van der Meij and Hoeksema, 2013) and described herein as Fungicola syzygia sp. nov. It is the third species assigned to the genus, and the fourth species recorded from mushroom corals.

\section{Material and methods}

Material was collected during fieldwork in Raja Ampat (Papua, Indonesia, Nov.-Dec. 2007), Bunaken National Marine Park (N Sulawesi, Indonesia, Dec. 2008), Ternate (Halmahera, Indonesia, Oct.-Nov. 2009), Semporna (E Sabah, Malaysia, Nov.-Dec. 2010), Lembeh Isl. (N Sulawesi, Indonesia, Jan.-Feb. 2012), and Kudat (N Sabah, Malaysia, Sep. 2012). A few additional samples were available from New Caledonia (2012), Payar Isl. (Malaysia, 2013), Loyalty Isl. (New Caledonia, 2014) and the Maldives (2014). Gall crabs were collected with their host coral and taken to the field station. After being photographed with a digital SLR camera with a 50 $\mathrm{mm}$ macro-lens, the crabs were preserved in $80 \%$ ethanol. The gall crabs are deposited in the collections of Naturalis Biodiversity Center in Leiden, the Netherlands (formerly Rijksmuseum van Natuurlijke Historie, collection coded as RMNH.Crus.D), and a paratype of Fungicola syzygia sp. nov. is deposited in the Lee Kong Chian Natural History Museum in Singapore (formerly Raffles Museum of Biodiversity Research, collection coded as ZRC). The mushroom coral identifications are based on revisions of the Fungiidae (Hoeksema, 1989; Gittenberger et al., 2011), all identifications were (confirmed) by Dr. Bert W. Hoeksema. Species authorities for the Fungiidae are provided in the list of material examined (Appendix).

Drawings were made with a stereo microscope with camera lucida. The chelipeds were drawn with the outer surface of the manus parallel to the plane of the paper, which somewhat distorts the other segments. Carapace lengths and widths were measured using an eyepiece micrometre. Abbreviations used: ovigerous, ovig.; MXP, maxilliped; P, pereiopod; PLP, pleopod; $\mathrm{CL}$, carapace length at midpoint; $\mathrm{CW}$, carapace width at widest point. Carapace measurements are given as $\mathrm{CL} \times \mathrm{CW}$.

\section{Nha Trang collections}

Fize and Serène $(1956,1957)$ described 16 new gall crab species in their monograph on the gall crabs of Vietnam and deposited the types in the museum of the Institute of Oceanography in Nha Trang (Vietnam). The Nha Trang collections were examined in October 2012 to search for the type material. Various specimens in the museum got displaced and subsequently lost during Vietnam's turbulent history, however, seven out of the 16 Fize and Serène's holotypes were located, including the types of Troglocarcinus fagei and T. utinomi (Fig. 1A-F). The allotype of T. utinomi was also located (Fig. $1 \mathrm{G}-\mathrm{I})$, but the vial that should have contained the allotype of T.fagei was empty, and this allotype is therefore considered lost. The list of material examined (see Appendix) includes all the Fungicola specimens that were located in the Nha Trang museum. Collection numbers were mentioned on labels on the outside of the collection jars and on labels inside the vials. In case of discrepancy, the information on the labels inside the vial was accepted as most likely the 'correct' information for the specimen(s) concerned. The locality data, 'Rte' (recolte) on the Vietnamese labels can be retrieved from Fize and Serène (1957).

Fize and Serène deposited duplicates of Fungicola specimens collected in Vietnam in the Muséum national d'Histoire naturelle (MNHN) in Paris, France. Additional specimens from Fize and Serène were unexpectedly encountered in the collections of the Natural History Museum (BMNH) in London, the United Kingdom. The details of this material are also included in the list of material examined.

\section{Molecular analyses}

For the molecular analyses specimens of Fungicola fagei and F. utinomi were included from many different host corals. Utinomiella dimorpha (Henderson, 1906) and Pseudocryptochirus viridis Hiro, 1938, associated with the coral genera Pocillopora and Turbinaria, respectively, were selected as outgroups because they belong to more distant clades within the monophyletic Cryptochiridae (van der Meij and Reijnen, 2014; van der Meij and Schubart, 2014).

Analyses of sequences from the mitochondrial cytochrome c oxidase subunit I gene (COI, partially, Folmer et al. (1994) and 16S mtDNA (16L2 and 16H10, Schubart (2009)) were used to infer phylogenetic relationships between the examined taxa. In addition, Histone H3 (H3) was used (Colgan et al., 2000). The reverse primer was optimized for gall crabs (H3_R SET: 5'-GCCGACMAGGTARGCCTCKG-'3).

DNA was isolated from the fifth pereiopod, using the QIAGEN DNeasy Kit according to the manufacturer's protocol for animal tissue. Maceration took place 


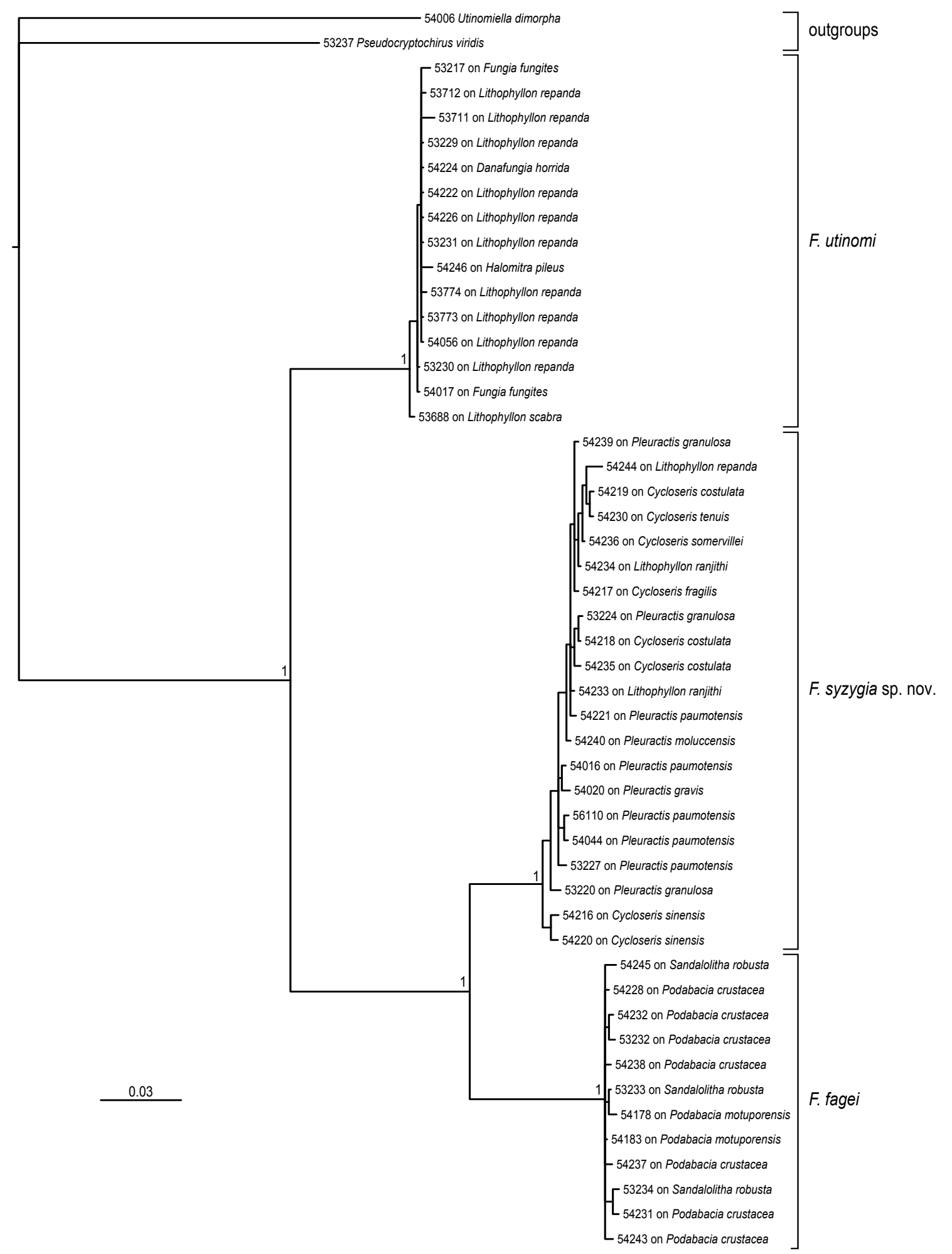

Fig. 2. Phylogeny reconstruction of the genus Fungicola based on a concatenated dataset of $16 \mathrm{~S}$ and COI mtDNA and H3 nDNA of 50 taxa (including outgroups). Topology derived from Bayesian inference 50\% majority rule, significance values are posterior probabilities. Numbers refers to collection numbers (RMNH.Crus.D, see material examined in the Appendix). 
overnight for approximately $18 \mathrm{hrs}$. The final elution step was performed with $100 \mu$ l elution buffer. Polymerase chain reaction was carried out with standard PCR conditions ( $2.5 \mu$ l PCR buffer, $0.5 \mu$ DNTP's, 1.0 $\mu \mathrm{l}$ primer $\mathrm{FW}, 1.0 \mu \mathrm{l}$ primer RV, $0.3 \mu \mathrm{l} \mathrm{Taq}, 18.7 \mu \mathrm{l}$ MilliQ and $1.0 \mu \mathrm{l}$ DNA template). Thermal cycling for $\mathrm{COI}$ and $16 \mathrm{~S}$ was as follows: initial denaturation at $95^{\circ} \mathrm{C}$ for five minutes, followed by 39 cycles of $95^{\circ} \mathrm{C}$ for five seconds, $47^{\circ} \mathrm{C}$ for one minute, and $72^{\circ} \mathrm{C}$ for one minute. This was followed by 10 minutes at $72^{\circ} \mathrm{C}$. For $\mathrm{H} 3$ the standard PCR conditions were adjusted to $13.7 \mu \mathrm{l}$ MilliQ and 5.0 $\mu \mathrm{l} \mathrm{Q}$-solution. Thermal cycling was as follows: initial denaturation at $95^{\circ} \mathrm{C}$ for three minutes, followed by 39 cycles of $95^{\circ} \mathrm{C}$ for ten seconds, $60^{\circ} \mathrm{C}$ for one minute, and $72^{\circ} \mathrm{C}$ for one minute. This was followed by 5 minutes at $72^{\circ} \mathrm{C}$. Sequences were assembled and edited in Sequencer 4.10.1. A total of 1520 base pairs are included in the three marker dataset $(\mathrm{n}=50$, including outgroups).

Sequences were aligned using ClustalW on the Guidance server (Penn et al.,2010), resulting in an alignment score of 0.991066 . Prior to the model-based phylogenetic analysis, the best-fit model of nucleotide substitution was identified for each gene partition by means of the Akaike Information Criterion (AIC) calculated with jModeltest (Posada, 2008), resulting in GTR+I for 16S, $\mathrm{GTR}+\mathrm{G}$ for COI and TIM2+G for H3. Because of the unavailability of TIM2 in MrBayes 3.1.2 (Ronquist and Huelsenbeck, 2003), I used the most complex GTR+G model of nucleotide substitution for H3. Bayesian inferences coupled with Markov chain Monte Carlo techniques (six chains) were run for 3,000,000 generations on the partitioned concatenated dataset, with a sample tree saved every 100 generations and the burnin set to $25 \%$. Likelihood scores stabilized at a value of 0.005774 . Consensus trees were visualized in FigTree v.1.3.1
(Rambaut, 2009). In addition, gene trees (H3 and concatenated $16 \mathrm{~S}+\mathrm{COI}$ ) were constructed with the same parameters as for the concatenated three marker dataset (see online supplementary material Figs S1 and S2).

An analysis was also conducted in MEGA 6.06 (Tamura et al., 2013) to estimate the evolutionary divergence over sequence pairs between a priori determined groups (MCL model, 1000 bootstraps). Only specimens for which sequences for all three markers were obtained were included in the analysis $(n=40)$.

\section{Results}

\section{Molecular analyses}

The analysis in MrBayes resulted in a tree with high posterior probabilities. Based on the results of this analysis and host specificity data a cryptic species of Fungicola was revealed, closely related to Fungicola fagei (Fig. 2). This new species is described as F. syzygia sp. nov. (see Appendix). The concatenated 16S + COI mtDNA (Fig. S1) has the same topology as the three marker phylogeny reconstruction, the $\mathrm{H} 3$ gene tree (Fig. S2) recovers $F$. utinomi as monophyletic, but does not distinguish between $F$. fagei and $F$. syzygia sp. nov.

The evolutionary divergence over sequence pairs was estimated for Fungicola fagei, F. syzygia sp. nov. and F. utinomi. In this analysis, the groups were determined a priori based on Fig. 2. There is about a $6 \%$ difference between $F$. fagei and $F$. syzygia sp. nov. and an $11 \%$ difference between $F$. fagei and $F$. utinomi. F. syzygia sp. nov. and $F$. utinomi have a difference of $9.2 \%$ (Table 1). Table 2 shows the intraspecific difference within the three species, which ranges from 0.1 to $0.4 \%$.
Table 1. Estimates of evolutionary divergence based on $16 \mathrm{~S}$, COI and $\mathrm{H} 3$. The number of base substitutions per site averaging over all sequence pairs between groups determined a priori is shown below the diagonal. Standard error (SE) estimates are shown above the diagonal.

Table 2. Estimates of evolutionary divergence based on $16 \mathrm{~S}$, COI and $\mathrm{H} 3$. The number of base substitutions per site averaging over all sequence pairs within groups determined a priori and the standard error (SE) estimates are shown.

\begin{tabular}{|c|c|c|c|}
\hline & $F$ fagei & F. syzygia sp. nov. & F. utinomi \\
\hline Fungicola fagei $(\mathrm{n}=10)$ & & 0.015 & 0.025 \\
\hline F. syzygia sp. nov. $(\mathrm{n}=21)$ & 0.064 & & 0.022 \\
\hline \multirow[t]{2}{*}{ F. utinomi $(\mathrm{n}=9)$} & 0.110 & 0.092 & \\
\hline & d. & SE & \\
\hline Fungicola fagei $(\mathrm{n}=10)$ & 0.003 & 0.001 & \\
\hline F. syzygia sp. nov. $(\mathrm{n}=21)$ & 0.004 & 0.001 & \\
\hline F. utinomi $(\mathrm{n}=9)$ & 0.001 & 0.001 & \\
\hline
\end{tabular}




\section{Host specificity}

Different host occurrences for Fungicola fagei and its sibling species $F$. syzygia sp. nov. (Fig. 2, Table S3) were observed. Fungicola fagei occurs only in corals belonging to Podabacia or Sandalolitha. Fungicola syzygia sp. nov. is predominantly associated with Cycloseris and Pleuractis, with a few records from Lithophyllon. Fungicola utinomi is mostly found in association with species of Danafungia, Fungia, Halomitra, and Lithophyllon, but its most common host is L. repanda.

\section{Discussion}

Species having a small size or hidden habitat are often referred to as 'cryptic'. Although gall crabs are small and live a hidden life inside their corals hosts and hence 'cryptic', cryptic species is herein referred to as two or more species that were previously classified as a single one because of (at least superficial) morphological similarities (Bickford et al., 2007). This definition is applicable to $F$. syzygia sp. nov., which is difficult to separate from $F$. fagei based on morphology alone (see description in Appendix). DNA taxonomy is becoming an indispensable tool for unravelling cryptic speciation. This especially holds true for endosymbionts which have prolonged relationships with their hosts that can lead to morphological stasis (e.g. Gittenberger and Gittenberger, 2010).

Fungicola syzygia sp. nov. and $F$. fagei are clearly separated based on DNA and host specificity (Fig. 2). Fungicola syzygia sp. nov. and $F$. fagei are more closely related to each other than to $F$. utinomi. The intraspecific variation is low (Tables 1-2). The mitochondrial markers $16 \mathrm{~S}$ and $\mathrm{COI}$ showed high resolution at species level (Fig. S1), contrary to the nuclear marker H3 (Fig. S2). The latter marker recovered $F$. utinomi as a monophyletic clade, except for RMNH. Crus.D.54246, which clustered basally to all other specimens. H3 did not distinguish between $F$. fagei and F. syzygia sp. nov. A study by Dinapoli et al. (2007) showed that $\mathrm{H} 3$ is most informative on genus level in heterobranch Gastropoda, making this marker a possible candidate for further reconstructions of the deeper phylogenetic relationships within the Cryptochiridae.

Fungicola syzygia sp. nov. and $F$. fagei can also be separated based on their host occurrence. The usual pattern among host-specific organisms is a common or 'preferred' host, with a number of other hosts less fre- quently inhabited (Norton and Carpenter, 1998). This seems to be the case in fungiid-associated gall crabs as well. The present results showed that Fungicola fagei was strictly associated with the sister genera Podabacia and Sandalolitha, with P. crustacea as the most common host. Fungicola syzygia sp. nov. is mostly associated with the genera Cycloseris and Pleuractis, with $P$. granulosa and P.paumotensis as most common hosts. Fungicola utinomi is associated with a wider range of related genera but is most often encountered in Lithophyllon repanda (Fize and Serène, 1957; van der Meij and Hoeksema, 2013; Fig. 2, Table S3). Hoeksema et al. (2012) mentioned that gall crabs are not very host specific, but at the time of writing, the new sibling species of Fungicola fagei was not yet discovered. It turns out that Fungicola species are specific to at least genus level. The specimens referred to as 'cryptochirid sp.' in Hoeksema et al. (2012) belonged to one of the, now four, known species associated with Fungiidae. The identifications of these specimens was hampered by being juvenile stages or needed back-up from molecular work.

Several fungiid species have so far not been found occupied by a gall crab, possibly because their coral morphology makes for an unsuitable habitat for gall crabs (e.g. long tentacles in Heliofungia actiniformis or very thin plate-like morphology in Halomitra clavator and Zoopilus echinatus). Other species have distributions outside the range in which the fieldwork was carried out and might therefore not yet have been found in association with gall crabs.

Kropp and Manning (1987) removed the concept of host specificity as a generic character for gall crabs, which was previously believed to be a reliable character to distinguish genera (Fize and Serène, 1957). Many changes have been recently made and proposed in scleractinian phylogeny and taxonomy, largely based on new insights coming from molecular data and microstructures (e.g. Gittenberger et al., 2011; Benzoni et al., 2012; Budd et al., 2012; Arrigoni et al., 2014; Huang et al., 2014). The inconsistencies in the generic placement of the gall crabs based on host affinity, as observed by Kropp (1990), are therefore likely related, at least in part, to past inconsistencies in scleractinian taxonomy.

\section{Acknowledgements}

Many thanks to Bùi Quang Nghị and Nguyễn Thị Mỹ Ngân (Institute of Oceanography, Nha Trang, Vietnam) for facilitating my visit to the institute and their indispensable help with locating the Fize and Serène material, to Laure Corbari and Paula Martin Lefèvre (Muséum national d'Histoire naturelle, Paris, France) 
for locating the French specimens of Fize and Serène, to Paul Clark (Natural History Museum, London, UK) for his help during my short visit, and to Karen Reed and Rafael Lemaitre (National Museum of Natural History, Smithsonian Institution, Washington D.C., USA) for their assistance during a collection visit in 2009. Bert Hoeksema (Naturalis) collected cryptochirids from Fungiidae over the last years, many of which were used in this study. Charles Fransen (Naturalis) helped to search for morphological characters distinguishing Fungicola fage $i$ and $F$. syzygia sp. nov. Chris Boyko (Dowling College and American Museum of Natural History) helped to identify the epicaridean parasite. Bastian Reijnen (Naturalis) is thanked for all his help during our visit to the Institute of Oceanography in Nha Trang, as well as help with photography and lab work. The beautiful line drawings in this manuscript were made by Inge van Noortwijk (Naturalis). The COI sequences were produced as part of the Naturalis Barcoding project. The fieldwork in Indonesia was organized by Naturalis and the Indonesian Institute of Sciences (LIPI), under the umbrella of Ekspedisi Widya Nusantara (E-Win). Fieldwork in Lembeh Strait in 2012 took place during a Marine Biodiversity Workshop based at the Bitung Field Station (LIPI), co-organized by Universitas Sam Ratulangi in Manado, N Sulawesi (Indonesia). I am grateful to LIPI and RISTEK for granting research permits. Bert Hoeksema (Naturalis) and Yosephine Tuti Hermanlimianto (RCO-LIPI) are acknowledged for all their efforts in organizing the various expeditions in Indonesia. The 2010 Semporna Marine Ecological Expedition was jointly organized by WWF-Malaysia, Universiti Malaysia Sabah's Borneo Marine Research Institute, Universiti Malaya's Institute of Biological Sciences and Naturalis, and was funded through WWF-Malaysia. The research permits for Malaysia were granted by the Economic Planning Unit, Prime Minister's Department, Sabah Parks and Department of Fisheries Sabah. The Tun Mustapha Park Expedition (TMPE) 2012 was jointly organized by WWF-Malaysia, Universiti Malaysia Sabah (UMS), Sabah Parks and Naturalis. TMPE was funded by the Ministry of Science, Technology and Innovation (MOSTI) and USAID Coral Triangle Support Partnership (CTSP). The research permits were granted by the Economic Planning Unit, Prime Minister's Department and Sabah Biodiversity Centre. Permits to sample from Payar Isl. were granted to Zarinah Waheed (Naturalis \& Universiti Malaysia Sabah) by the Economic Planning Unit, Prime Minister's Department Malaysia, and the Department of Marine Park Malaysia. Collecting in New Caledonia (2012) was done during the mission CORALCAL 4. Provinces Sud and Nord of New Caledonia provided sampling permits. Loyalty Island samples were collected during the BIBELOT campaign in 2014 onboard RV Alis of IRD at Nouméa. Sampling permits were granted by the Loyalty Islands Province, New Caledonia. For the samples from the Maldives the help of the University of MilanoBicocca Marine Research and High Education Centre in Magoodhoo, the Ministry of Fisheries and Agriculture, Republic of Maldives and the community of Maghoodhoo, Faafu Atoll is gratefully acknowledged. Funding for the several fieldwork trips was provided by the AM Buitendijkfonds, LB Holthuisfonds, JJ ter Pelkwijkfonds (all Naturalis), Schure-Beijerinck-Poppingfonds (KNAW), Stichting Fonds Dr C van Tussenbroek (N Ongerboerfonds), LUF International Study Fund (Leiden University) and the Van Tienhoven Foundation for International Nature Protection. Travel to the Smithsonian Institution was funded by a 2009 EDIT Women in Science Fellowship. I am grateful to Peter Castro and Roy Kropp for their constructive comments on an earlier version of this manuscript.

\section{References}

Arrigoni R, Richards ZT, Chen CA, Baird AH, Benzoni F. 2014. Taxonomy and phylogenetic relationships of the coral genera Australomussa and Parascolymia (Scleractinia, Lobophylliidae). Contributions to Zoology 83: 195-215.

Benzoni F, Arrigoni R, Stefani F, Stolarski J. 2012. Systematics of the coral genus Craterastrea (Cnidaria, Anthozoa, Scleractinia) and description of a new family through combined morphological and molecular analyses. Systematics and Biodiversity 10: 417-433.

Bickford D, Lohman DJ, Sodhi NS, Ng PKL, Meier R, Winker K, Ingram KK, Das I. 2007. Cryptic species as a window on diversity and conservation. Trends in Ecology \& Evolution 22: $148-155$.

Bos AR. 2012. Fish (Gobiidae and Labridae) associated with the mushroom coral Heliofungia actiniformis (Scleractinia: Fungiidae) in the Philippines. Coral Reefs 31: 133.

Budd AF, Fukami H, Smith ND, Knowlton N. 2012. Taxonomic classification of the reef coral family Mussidae (Cnidaria: Anthozoa: Scleractinia. Zoological Journal of the Linnean Society 166: 465-529.

Castro P. 1988. Animal symbioses in coral reef communities: a review. Symbiosis 5: 161-184.

Colgan DJ, Ponder WF, Eggler PE. 2000. Gastropod evolutionary rates and phylogenetic relationships assessed using partial rDNA and histone H3 sequences. Zoologica Scripta 29: 29-63.

Dinapoli A, Tamer C, Franssen S, Naduvilezhath L, KlussmannKolb A. 2007. Utility of H3-Genesequences for phylogenetic reconstruction - a case study of heterobranch Gastropoda. Bonner zoologische Beiträge 55: 191-202.

Fize A, Serène R. 1956. Note préliminaire sur huit espèces nouvelles, dont une d'un genre nouveau, d'Hapalocarcinidae. Bulletin de la Société zoologique de France 80(5-6): 375-378, figs. 1-2.

Fize A, Serène R. 1957. Les Hapalocarcinidés du Việt-Nam. Mémoires de l'Institut Océanographique de Nhatrang 10: 1-202, pls. 1-18.

Folmer O, Black M, Hoeh W, Lutz R, Vrijenhoek R. 1994. DNA primers for amplification of mitochondrial cytochrome c oxidase subunit I from diverse metazoan invertebrates. Molecular Marine Biology and Biotechnology 3: 294-297.

Gittenberger A, Gittenberger E. 2005. A hitherto unnoticed adaptive radiation: epitoniid species (Gastropoda: Epitoniidae) associated with corals (Scleractinia). Contributions to Zoology 74: 125-203.

Gittenberger A, Gittenberger E. 2010. Cryptic, adaptive radiation of endoparasitic snails: sibling species of Leptoconchus (Gastropoda: Coralliophilidae) in corals. Organisms Diversity \& Evolution 11: 21-41.

Gittenberger A, Reijnen BT, Hoeksema BW. 2011. A molecular based phylogeny reconstruction of mushroom corals (Scleractinia: Fungiidae) with taxonomic consequences and evolutionary implications for life history traits. Contributions to Zoology 80: 107-132.

Henderson JR. 1906. On a new species of coral-infesting crab taken by the R.I.M.S. 'Investigator' at the Andaman Islands. The Annals and Magazine of Natural History, series 7 18(105): 211-219. 
Hiro F. 1938. A new coral-inhabiting crab, Pseudocryptochirus viridis gen. et spec. nov. (Hapalocarcinidae, Brachyura). Zoological Magazine Tokyo 50: 149-151.

Hoeksema BW. 1989. Taxonomy, phylogeny and biogeography of mushroom corals (Scleractinia: Fungiidae). Zoologische Verhandelingen Leiden 254: 1-295.

Hoeksema BW, Kleemann K. 2002. New records of Fungiacava eilatensis Goreau et al., 1968 (Bivalvia: Mytilidae) boring in Indonesian mushroom corals (Scleractinia: Fungiidae). Basteria 66: 25-30.

Hoeksema BW, van der Meij SET, Fransen CHJM. 2012. The mushroom coral as a habitat. Journal of the Marine Biological Association of the United Kingdom 92: 647-663.

Huang D, Benzoni F, Fukami H, Knowlton N, Smith ND, Budd AF. 2014. Taxonomic classification of the reef coral families Merulinidae, Montastraeidae and Diploastraeidae (Cnidaria: Anthozoa: Scleractinia). Zoological Journal of the Linnean Society 171: 277-355.

Kleemann K, Hoeksema BW. 2002. Lithophaga (Bivalvia: Mytilidae), including a new species, boring in mushroom corals (Scleractinia: Fungiidae) at South Sulawesi, Indonesia. Basteria 66: 11-24.

Kropp RK, Manning RB. 1987. The Atlantic gall crabs, family Cryptochiridae (Crustacea: Decapoda: Brachyura). Smithsonian Contributions to Zoology 462: 1-21.

Kropp RK. 1990. Revision of the genera of gall crabs (Crustacea: Cryptochiridae) occurring in the Pacific Ocean. Pacific Science 44: 417-448.

Kropp RK. 1994. The gall crabs (Crustacea: Decapoda: Brachyura: Cryptochiridae) of the Rumphius expeditions revisited, with descriptions of three new species. Raffles Bulletin of Zoology 42: 521-538.

Meij SET van der. 2014. Host species, range extensions, and an observation of the mating system of Atlantic shallow-water gall crabs (Decapoda: Cryptochiridae). Bulletin of Marine Science 90: 1001-1010.

Meij SET van der, Hoeksema BW. 2013. Distribution of gall crabs inhabiting mushroom corals on Semporna reefs, Malaysia. Marine Biodiversity 43: 53-59.

Meij SET van der, Reijnen BT. 2014. The curious case of Neotroglocarcinus dawydoffi (Brachyura, Decapoda): biogeographic patterns resulting from isolation. Systematics and Biodiversity 12: 503-512.

Meij SET van der, Schubart CD. 2014. Monophyly and phylogenetic origin of the gall crab family Cryptochiridae (Decapoda: Brachyura). Invertebrate Systematics 28: 491-500.

Ng PKL, Guinot D, Davie PJF. 2008. Systema Brachyurorum: Part I. An annotated checklist of extant brachyuran crabs of the world. The Raffles Bulletin of Zoology Supplement No. 17: 1-286.
Norton DA, Carpenter MA. 1998. Mistletoes as parasites: host specificity and speciation. Trends in Ecology \& Evolution 13: 101-105.

Penn O, Privman E, Ashkenazy H, Landan G, Graur D, Pupko T. 2010. GUIDANCE: a web server for assessing alignment confidence scores. Nucleic Acids Research 38 (Web Server issue): W23-W28.

Posada D. 2008. jModelTest: Phylogenetic Model Averaging. Molecular Biology and Evolution 25: 1253-1256.

Rambaut A. 2009. FigTree 1.3.1. [http://tree.bio.ed.ac.uk/software/figtree/]

Ronquist F, Huelsenbeck JP. 2003. MRBAYES 3: Bayesian phylogenetic inference under mixed models. Bioinformatics 19: $1572-1574$.

Schubart CD. 2009. Mitochondrial DNA and decapod phylogenies; the importance of pseudogenes and primer optimization. Pp. 47-65 in: Martin JW, Crandall KA, Felder DL, eds, Crustacean Issues 18: Decapod Crustacean Phylogenetics. Boca Raton, Florida: Taylor and Francis/CRC Press.

Serène R. 1967. Note sur la taxonomie et la distribution geographique des Hapalocarcinidae (Decapoda-Brachyura). Reprinted from the Proceedings of Symposium on Crustacea - part 1, 395-398.

Serène R, Romimohtarto K, Moosa MK. 1974. The Hippidea and Brachyura collected by the Rumphius Expedition I. Oseanologi di Indonesia 1: 17-26.

Takeda M, Tamura Y. 1979. Coral-inhabiting crabs of the family Hapalocarcinidae from Japan. I. Three species obtained from mushroom coral, Fungia. Bulletin National Science Museum Tokyo, Series A (Zoology) 5: 183-194.

Takeda M, Tamura Y. 1981. Coral-inhabiting crabs of the family Hapalocarcinidae from Japan. VIII. Genus Pseudocryptochirus and two new genera. Bulletin of the Biogeographical Society of Japan 36: 14-27, figs. 1-3, pi. 1-4.

Takeda M, Tamura Y. 1986. Coral-inhabiting crabs of the family Hapalocarcinidae from Japan. XI. Biogeographical distribution. Bulletin of the Biogeographical Society of Japan 41: 61-70, figs. 1-9.

Tamura K, Stecher G, Peterson D, Filipski A, Kumar S. 2013. MEGA6: Molecular Evolutionary Genetics Analysis version 6.0. Molecular Biology and Evolution 30: 2725-2729.

Vehof J, SET van der Meij, M Türkay, C Becker (in press). Female reproductive morphology of coral-inhabiting gall crabs (Crustacea: Decapoda: Brachyura: Cryptochiridae). Acta Zoologica. doi: 10.1111/azo.12111.

Received: 29 September 2014

Revised and accepted: 27 November 2014

Published online: 10 February 2015

Editor: R. Vonk 


\section{Online Supplementary Information}

S1. Phylogeny reconstruction of the genus Fungicola based on 16S and COI mtDNA of 47 taxa (including outgroups). Topology derived from Bayesian inference 50\% majority rule, significance values are posterior probabilities. Numbers refers to collection numbers (RMNH.Crus.D, see Table S3). Likelihood scores stabilized at a value of 0.008292 .

S2. Phylogeny reconstruction of the genus Fungicola based on H3 nDNA of 45 taxa (including outgroups). Topology derived from Bayesian inference 50\% majority rule, significance values are posterior probabilities. Numbers refers to collection numbers (RMNH.Crus.D, see Table S3). Likelihood scores stabilized at a value of 0.007425.

S3. List of material examined in Naturalis Biodiversity Center (Leiden, The Netherlands), including GenBank Accession numbers. 


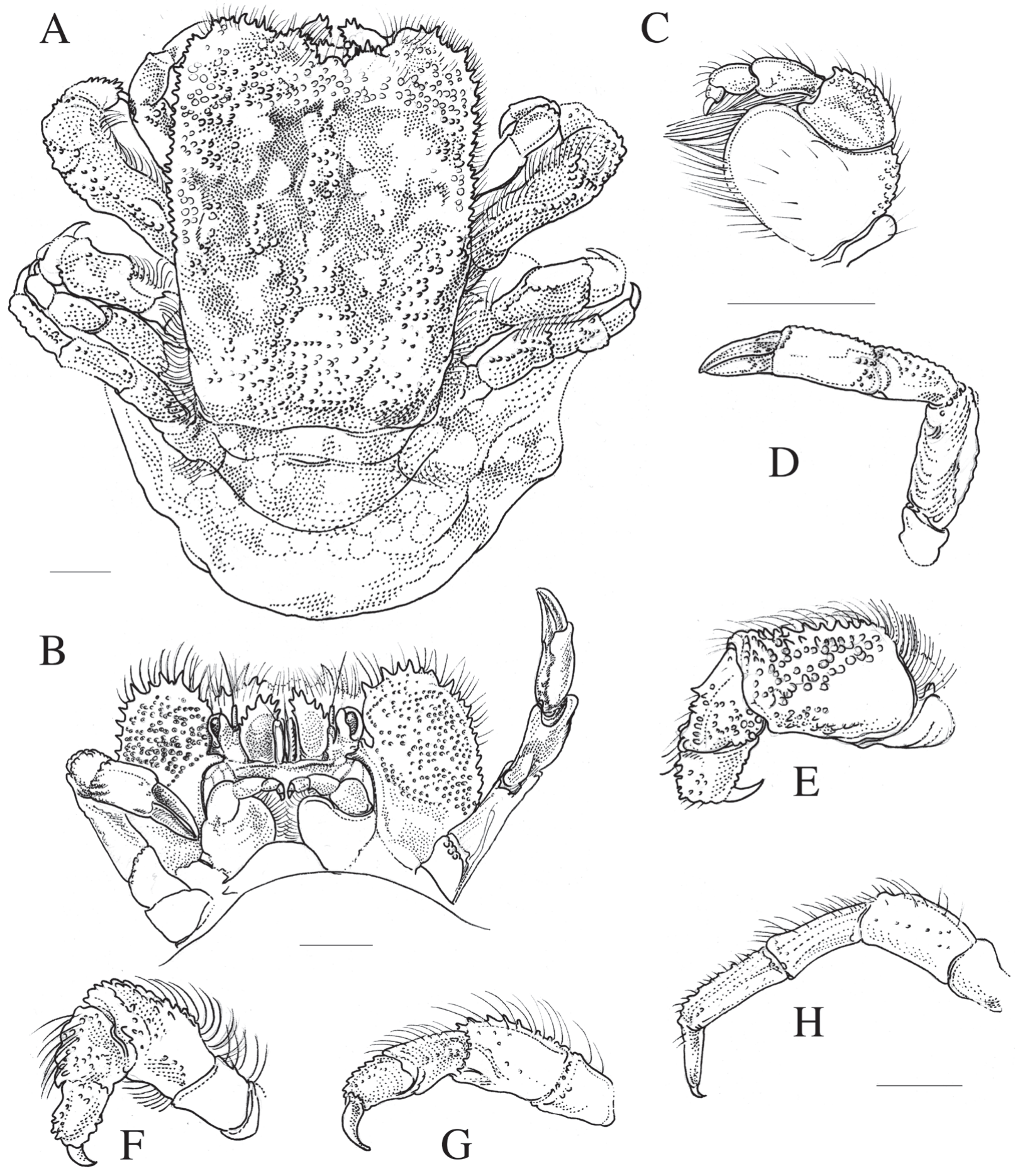

Fig. 3. Fungicola utinomi (RMNH.Crus.D 53229). A, habitus, dorsal view; B, anterolateral margin of carapace, ventral view; C, MXP3; D, left P1 (cheliped); E, left P2; F, left P3; G, left P4; H, left P5. Scale bars 1 mm, D-H share scale bar. 


\section{Appendix}

Systematic account

Family Cryptochiridae Paul'son, 1875

Genus Fungicola Serène, 1967

Fungicola.- Fize and Serène, 1957: 122 [name unavailable]

Fungicola Serène, 1967: 396

Fungicora.- Takeda and Tamura, 1986: 64 [erroneous spelling]

Type species. Troglocarcinus utinomi Fize and Serène, 1956: 377.

Diagnosis. Carapace rectangular to squaroid, longer than broad, widest anterior to midlength, flat in lateral view, not deflected anteriorly, surface covered with granules, mesogastric region slightly inflated, cardiointestinal region outlined; pterygostomial region fused to carapace; epistome with parallel lateral ridges; lateral lobe of antennule oval, extending slightly beyond eyestalk; antennal segment two longer than broad, distal margin lacking lateral spine; MXP3 with exopod, merus with small distolateral projection, mesial margin granulated, with setae; ventral thorax longer than broad; P1 cutting edges entire; P2 merus with distomesial projection; P3-4 coxae with well-developed anterior lobes; PLP3 of female uniramous; male abdomen triangle-shaped (adapted from Kropp, 1990).

Remarks. Fize and Serène (1957) described the subgenus Fungicola in the genus Troglocarcinus based on the following characteristics: 1) flat carapace on the dorso-ventral side, 2) flat dorsal surface in the shape of a spatula without much relief, 3) anterior-lateral angle shaped as a large round lobe, 4) rhomboid outline of the male abdomen, with the segments 3-5 enlarged.

Fize and Serène unfortunately did not designate a type species. Serène (1967) elevated the subgenus to genus level and designated T. utinomi as the type species. Species in the genus Fungicola are only known to occur in association with fungiid corals.

Fungicola utinomi (Fize and Serène, 1956)

Figs 1C-I, 3A-H

Troglocarcinus utinomi Fize and Serène, 1956: 377, fig. $2 \mathrm{E}$
Troglocarcinus (Fungicola) utinomi.- Fize and Serène, 1957: 124

Fungicola utinomii.- Serène, 1967: 396 [unjustified emendation]

Pseudocryptochirus ishigakiensis Takeda and Tamura, 1979: 188

Hiroia ishigakiensis.- Takeda and Tamura, 1981: 20

Type locality. Nha Trang, Vietnam

Holotype. E.37.277 ('Type' according to Fize and Serène, 1957) in the Institute of Oceanography in Nha Trang, Vietnam; allotype: E.37.766 (Fig. 2C-I), collected from Fungia fungites (Linnaeus, 1758).

Material examined. Institute of Oceanography (Nha Trang, Vietnam): label E.37.277 (Rte 1560), in jar E.37.277, poor condition, holotype, 1 ovig. f; label E.37.183 (Rte 1555), in jarE.37.183 (Rte 1555) - E.37.776 (Rte 1569), good condition; label E.37.184 (Rte 1555), in jar E.37.183 (Rte 1555) - E.37.776 (1569), empty vial; label E.37.271 (Rte 1560), in jar E.37.898-38.276 (Rte 1589), residue; label E.37.272 (Rte 1560), in jar E.37.89838.276 (Rte 1589), empty vial; label E.37.275 (Rte 1560), in jar E.37.898-38.276 (Rte 1589), residue, on Fungia sp.; label E.37.276 (Rte 1560), in jar E.37.183 (Rte 1555) E.37.776 (Rte 1569), reasonable condition; label E.37.283 (Rte 1560), in jar E.39.041 (1635) - E.39.217 (1641), good condition; label E.37.554 (Rte 1569), in jar E.37.183 (Rte 1555) - E.37.776 (Rte 1569), reasonable condition; label E.37.672 (Rte 1579), in jar E.39.041 (1635) - E.39.217 (1641), fair/reasonable condition; label E.37.673 (Rte 1579), in jar E.39.041 (1635) - E.39.217 (1641), good condition; label E.37.763 (Rte 1582), in jar E.39.041 (1635) - E.39.217 (1641), translucent but fair condition; label E.37.764 (Rte 1582), in jar E.39.041 (1635) - E.39.217 (1641), good condition; label E.37.765 (Rte 1582), in jar E.39.041 (1635) - E.39.217 (1641), fair condition; label E.37.766 (Rte 1569), in jar E.37.183 (Rte 1555) - E.37.776 (Rte 1569), fair condition, some pereiopods missing, allotype; label E.37.818 (Rte 1585), in jar E.39.041 (1635) - E.39.217 (1641), good condition; label E.37.898 (Rte 1589), in jar E.37.898-38.276 (Rte 1589), translucent and poor condition; label E.39.203 (Rte 1641), in jar E.37.183 (Rte 1555) - E.37.776 (1569), fair; label E.39.206 (Rte 1641), in jar E.39.041 (1635) - E.39.217 (1641), good condition; label E.39.207 (Rte 1641), in jar E.37.89838.276 (Rte 1589), residue, on Fungia sp.; label unreadable, in jar E.39.041 (1635) - E.39.217 (1641), good condition; jar E.39.041 (1635) - E.39.217 (1641) contains label 


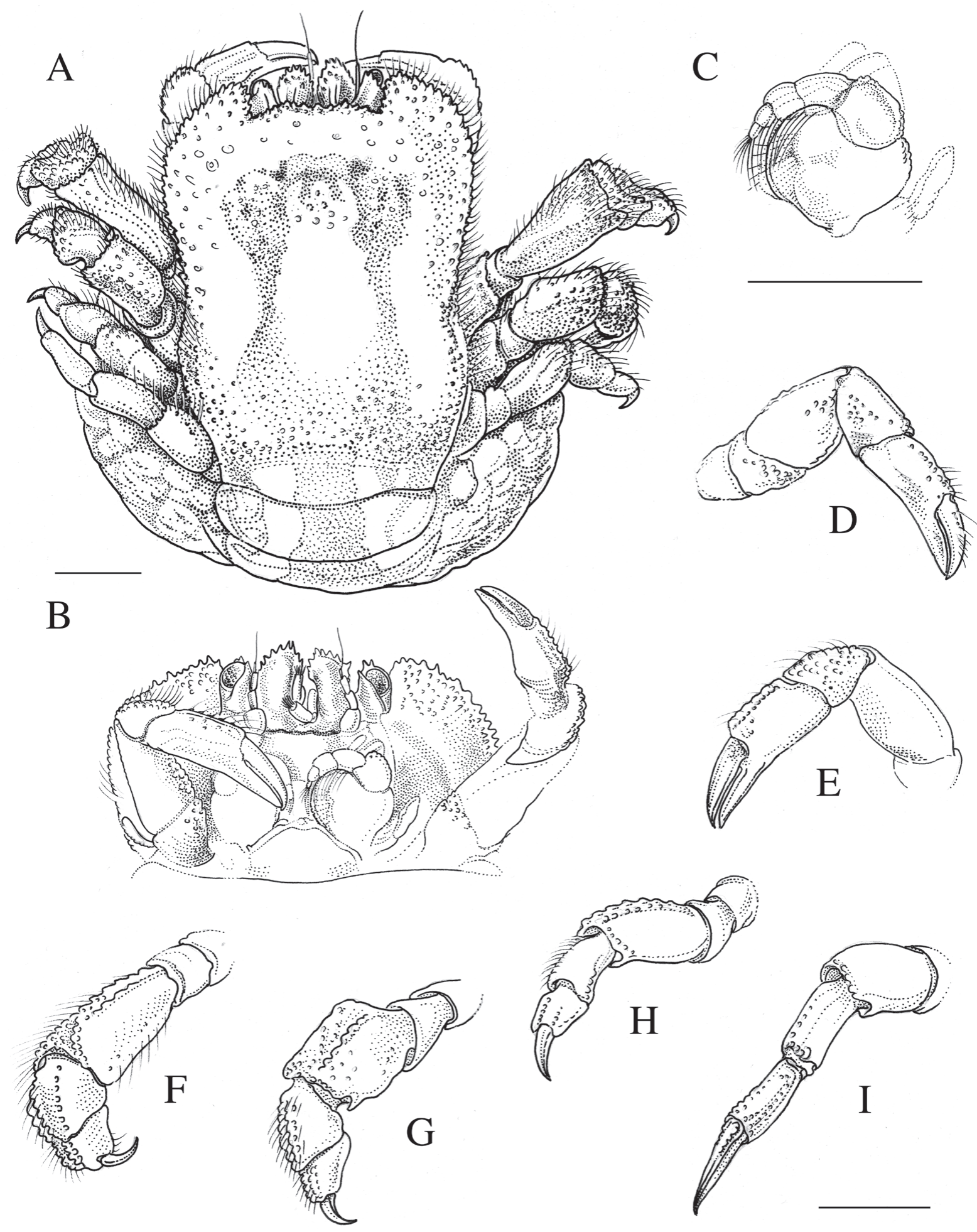

Fig. 4. Fungicola fagei (RMNH.Crus.D 53234). A, habitus, dorsal view; B, anterolateral margin of carapace, ventral view; C, MXP3; D, right P1 (cheliped); E, left P1 (cheliped); F, left P2; G, left P3; H, left P4; I, left P5. Scale bars 1 mm, B, D-I share a scale bar. 
E.39.205 (Rte 1641) but no vial. Muséum national d'Histoire naturelle (Paris, France): MNHNIU-2014-10108 (was E.38.333 (Rte 1614)), good condition, 1 ovig. f, on Fungia [= Lithophyllon] repanda; MNHNIU-2014-10107 (was E.38.425), good condition, $1 \mathrm{~m}$, on Fungia [= Lithophyllon] repanda. Natural History Museum (London, UK): BMNH.1958.1020.17-18 contains: E.39.336 (Rte 1644), good condition, 1 ovig. f, on Fungia sp.; E.39.337 (Rte 1644), good condition, 1 m, on Fungia sp. Naturalis Biodiversity Center (Leiden, The Netherlands): see Table S3.

Diagnosis. Carapace rectangular, longer than broad, depressed, anterior half broader than posterior half, surface covered with small, low granules in posterior half, larger and rather spiniform in anterior; median gastric region moderately convex and its posterior part only indistinctly separated from cardio-intestinal region, branchial regions hardly separated from both, mid-gastric, cardio-intestinal regions by very shallow furrows; front moderately concave, armed with spines of different size; internal orbital nearly reaching level of external; antero-lateral borders armed with spines and forming a convex lobe, lateral borders behind it straight or slightly converging. Cheliped slender; upper and external faces of merus, carpus and palm covered with fine granules. Upper face of coxae of pereiopods 3-4 with small forward protruding lobe. Carapace with striking brown, white patterns (visible in ethanol), pereiopods banded. For a full description see Fize and Serène (1957); for a colour figure of $F$. utinomi see Van der Meij and Schubart (2014: Fig. 1).

Host corals. Fungicola utinomi inhabits at least nine coral species belonging to eight genera, but is most often recorded from Lithophyllon repanda (Fig. 2, Table S3). In $L$. repanda, $F$. utinomi lives in an oval cavity with overhanging canopy, which can be raised above the coral surface (see Fize and Serène, 1957: Pl. XIII A-C; Takeda and Tamura, 1979: Pl. 1A-D, Pl 2A-D).

Distribution range. Fungicola utinomi has so far been documented from Nha Trang, Vietnam (Fize and Serène, 1957); Maluku, Indonesia (Rumphius I expedition, Serène et al., 1974); Semporna, Malaysia (van der Meij and Hoeksema, 2013); Ishigaki-jima and Kuroshima, Okinawa, Japan (Takeda and Tamura, 1979); and Palau and Guam in Micronesia (Kropp, 1990). New records from this study include Raja Ampat, Manado, Lembeh and Ternate in Indonesia, and Payar Isl. and Kudat in Malaysia.
Remarks. According to Kropp (1990) the location of the holotype is unknown; however, the holotype and the allotype were located in the Institute of Oceanography in Nha Trang (Fig. 2C-F).

Fungicola fagei (Fize and Serène, 1956)

Figs 1A-B, 4A-I, 7F-G

Troglocarcinus fagei Fize and Serène, 1956: 378, fig. 2F Troglocarcinus (Fungicola) fagei.- Fize and Serène 1957: 131

Type locality. Nha Trang, Vietnam

Holotype. E.38.444 ('Type' according to Fize and Serène, 1957) in the Institute of Oceanography in Nha Trang, Vietnam (Fig. 2A-B); allotype: E.37.727, collected from Sandalolitha dentata Quelch, 1884 (but see section on host corals).

Material examined. Institute of Oceanography (Nha Trang, Vietnam): E.38.444 (Rte 1614), no label on jar, good condition, holotype, 1 ovig. f; E.37.458 (Rte 1569), in jar E.37.458, residue; E.37479 (Rte 1569), in jar E.37479-39.215 (Rte 1641), empty vial; E.37.727 (Rte 1581), in jar E.37.479-39.215 (Rte 1641), empty vial, allotype; E.39.210 (Rte 1641), in jar E.37.458, poor condition; E.39.213 (1641), in jar E.37.479-39.215 (Rte 1641), empty vial, on Parahalomitra [= Sandalolitha] robusta; E.39.215 (Rte 1641), in jar E.37.479-39.215 (Rte 1641), empty vial, on Parahalomitra [= Sandalolitha] robusta; jar E.37.479-39.215 (Rte 1641) contains one label without vial,E.38.334 (Rte 1614). Muséum national d'Histoire naturelle (Paris, France): MNHN-IU-2009-2245 (was E.37.729 (Rte 1581)), pereiopods present but not attached to carapace, $1 \mathrm{~m}$, on Parahalomitra [= Sandalolitha] robusta; MNHN-IU-2009-2246 (was E.37.728 (Rte 1581), good condition, 1 ovig. f, on Parahalomitra [= Sandalolitha] robusta. Naturalis Biodiversity Center (Leiden, The Netherlands): see Table S3.

Diagnosis. Carapace subrectangular, longer than broad, depressed, anterior half broader than posterior half, surface covered with fine granules; median gastric region feebly convex, its posterior part not separated from cardio-intestinal region, branchial regions separated from mid-gastric and cardio-intestinal regions by shallow furrows; front moderately concave; internal orbital angle falling much shorter than external; antero-lateral borders armed with spinules, moderately convex, lateral borders behind it slightly concave. Cheliped not 


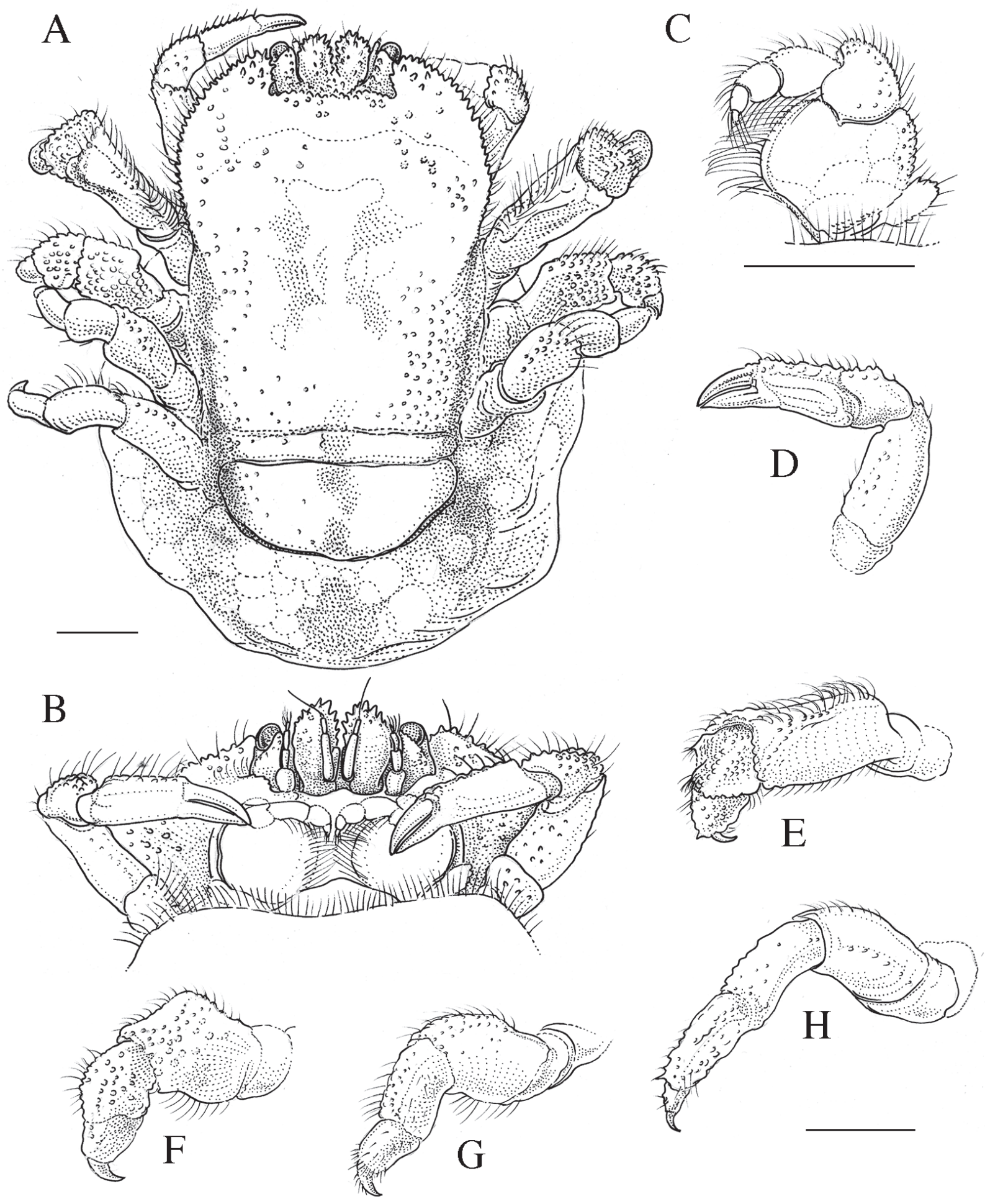

Fig. 5. Holotype Fungicola syzygia sp. nov. (RMNH.Crus.D.53220). A, habitus, dorsal view; B, anterolateral margin of carapace, ventral view; C, MXP3; D, left P1 (cheliped); E, left P2; F, left P3; G, left P4; H, left P5. Scale bars 1 mm, B, D-H share scale bar. 
stout; merus as well as upper borders of carpus, palm covered with fine granules. Upper face of coxae of third to fifth pereiopods with small forward protruding lobe. Carapace, pereiopods a dull beige-grey, semi-translucent. For a complete description of $F$. fagei see Fize and Serène (1957).

Host corals. Fungicola fagei can be found inhabiting flattened pits lodged between septae (see Fize and Serène, 1957: Pl. XIII D-F). According to Fize and Serène (1957) Fungicola fagei is associated with Parahalomitra robusta [= Sandalolitha robusta]. Based on Pl. XIII, fig. D-E in Fize and Serène (1957), however, this coral species should instead be identified as Sandalolitha dentata (B.W. Hoeksema, pers. comm.). The host genera of F. fage $i$ are the attached Podabacia and the free-living Sandalolitha, two closely related genera. Podabacia crustacea is the most common host, and $P$. sinai is a new host for $F$. fagei (Table S3).

Distribution range. Fungicola fage $i$ has is so far known from Nha Trang, Vietnam (Fize and Serène, 1957); Maluku, Indonesia (Serène et al., 1974); Semporna, Malaysia (van der Meij and Hoeksema, 2013); and Palau and Guam in Micronesia (Kropp, 1990). New records herein are New Caledonia and Raja Ampat and Ternate in Indonesia. A record of $F$. fagei from Japan by Takeda and Tamura (1979), collected from Fungia [=Pleuractis] paumotensis, most likely constitutes $F$. syzygia sp. nov. (see remarks in the species description of $F$. syzygia sp. nov).

Remarks. Kropp (1990) stated that the location of the holotype was unknown; however, the type was located in the Institute of Oceanography in Nha Trang and is in relatively good condition. The allotype was not found and is considered lost. Out of the other material mentioned by Fize and Serène only sample E. 39.210 was located, samples E. 37.458, E.37.471, E.37.727,E.37.729, E.38.334 and E.39.211-215 appear to be lost.

Fungicola syzygia sp. nov.

Figs 5A-H, 6A-K, 7A-E

?Fungicola fagei.- Takeda and Tamura (1979: Fig. 2A-D)

?Fungicola sp. - Ng et al. (2008: Fig. 156)

Type locality. Sulamadaha Bay, Ternate, Indonesia (N $\left.00^{\circ} 51^{\prime} 58^{\prime \prime}, \mathrm{E} 127^{\circ} 19^{\prime} 53^{\prime \prime}\right)$
Type material. Naturalis Biodiversity Center (Leiden, The Netherlands). Holotype: RMNH. Crus.D.53220, host Pleuractis granulosa (Klunzinger, 1879), 26.x.2009, 1 ovig. female $(4.0 \times 3.8)$, leg. SET van der Meij / BW Hoeksema (the holotype will be deposited in the Museum Zoologicum Bogoriense, Bogor, Indonesia with catalogue number MZB Cru 4130); allotype: RMNH.Crus.D.53224 (male), Tanjung Pasir Putih, Ternate, Indonesia (N 0051'50", E 127 20'36"), host Pleuractis granulosa (Klunzinger, 1879), 02. xi.2009, 1 male $(2.5 \times 2.3)$, leg. SET van der Meij; paratypes: RMNH.Crus.D. 53225, Tanjung Ratemu (S of river), Ternate, Indonesia (N 0054'24" E 127 29'17"), host Pleuractis granulosa (Klunzinger, 1879), 05. xi.2009, 1 non-ovig. female $(4.3 \times 4.3)$, leg. SET van der Meij; RMNH.Crus.D.53226, Pilongga N, Tidore, Indonesia (N 00 $42^{\prime} 49^{\prime \prime}$ E $\left.127^{\circ} 28^{\prime} 45^{\prime \prime}\right)$, host Pleuractis granulosa (Klunzinger, 1879), 12.xi.2009, 1 ovig. female (5.1 $\times 4.6$ ), leg. SET van der Meij; Lee Kong Chian Natural History Museum (Singapore). ZRC 2015.0006 (ex. RMNH.Crus.D.53219), Sulamadaha Bay, Ternate, Indonesia (N 0051'58", E 127 ${ }^{\circ} 19^{\prime} 53^{\prime \prime)}$, host Pleuractis granulosa (Klunzinger, 1879), 26.x.2009, 1 ovig. female (5.3 $\times 5.3$ ), leg. BW Hoeksema.

Material examined. Naturalis Biodiversity Center (Leiden, The Netherlands): see Table S3.

Description of holotype. Carapace (Fig. 5A) subrectangular to squaroid, longer than broad, anterior half rounded, broader than posterior half, surface covered with fine granules; flat in lateral view, not deflected anteriorly; cardio-intestinal region outlined; sharp internal orbital angle; frontal margin, anterolateral borders armed with spinules, few setae; anterolateral border moderately convex; lateral borders not clearly defined, somewhat concave. Pterygostomial region fused to carapace.

Ocular peduncles (Fig. 5B) granulated on distal margin, cornea round to oval, longer than broad; antennule same length as ocular peduncles; antennal segment 2.5 times longer than broad, extending beyond eyestalk, distal margin with several lateral spines.

MXP3 (Fig. 5C) exopod subrectangular, reaching approx. $1 / 2$ length of ischium, with tubercles and setae; ischium subquadrangular, smooth, mesial and distal margin slightly rounded, anteromesial lobe with setae, distal margin with tubercles; merus with distolateral projection, anterolateral margin of merus with tubercles and setae; distal portion of carpus with tubercles and setae; dactylus with bundle of long setae. 

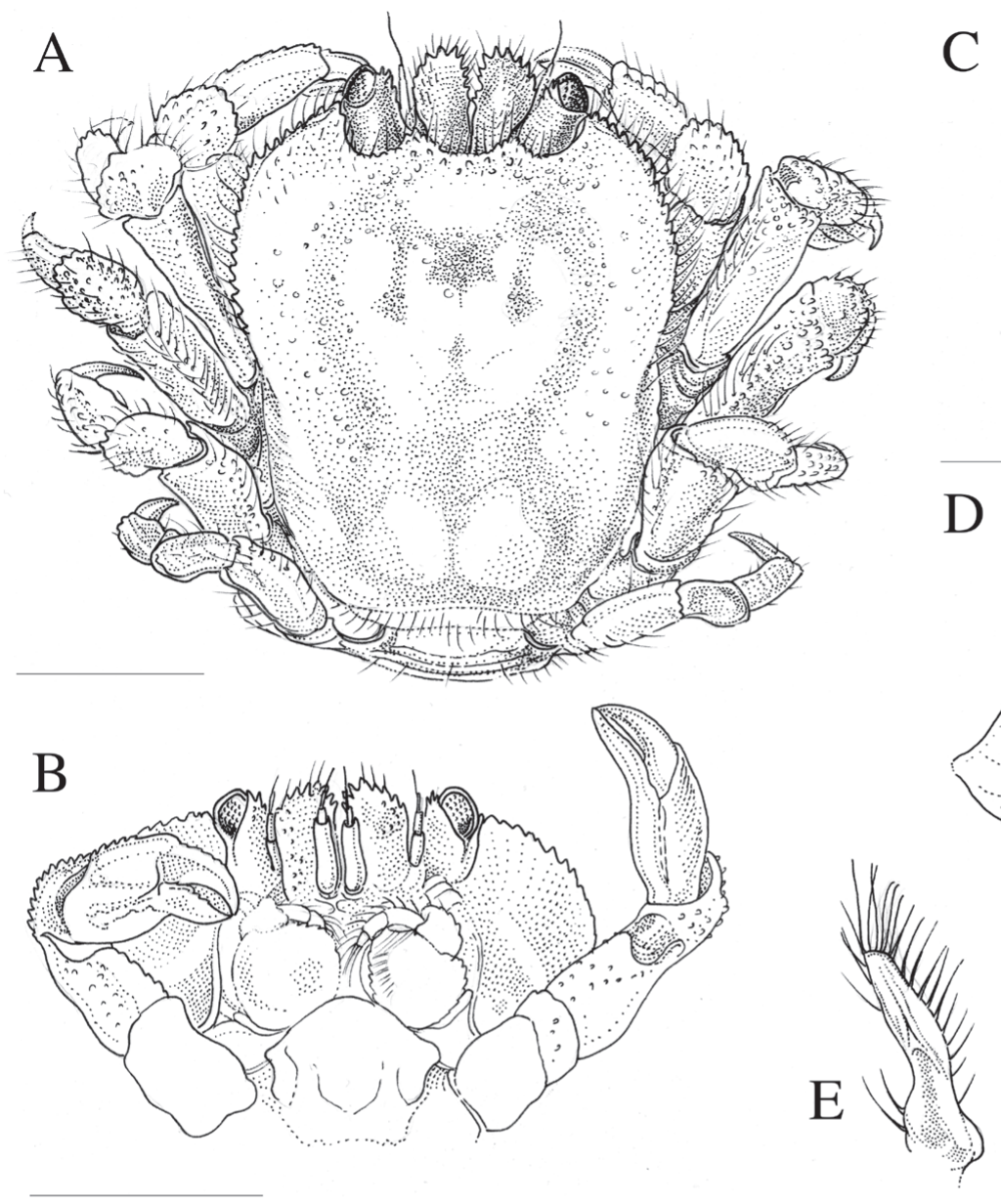

$\mathrm{C}$

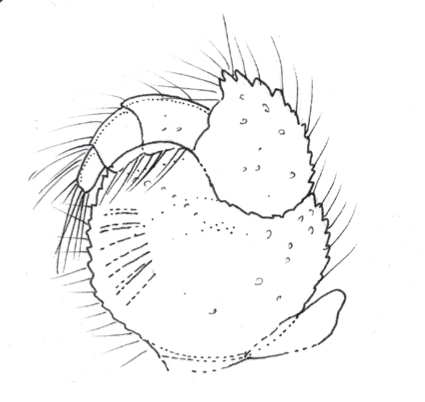

D
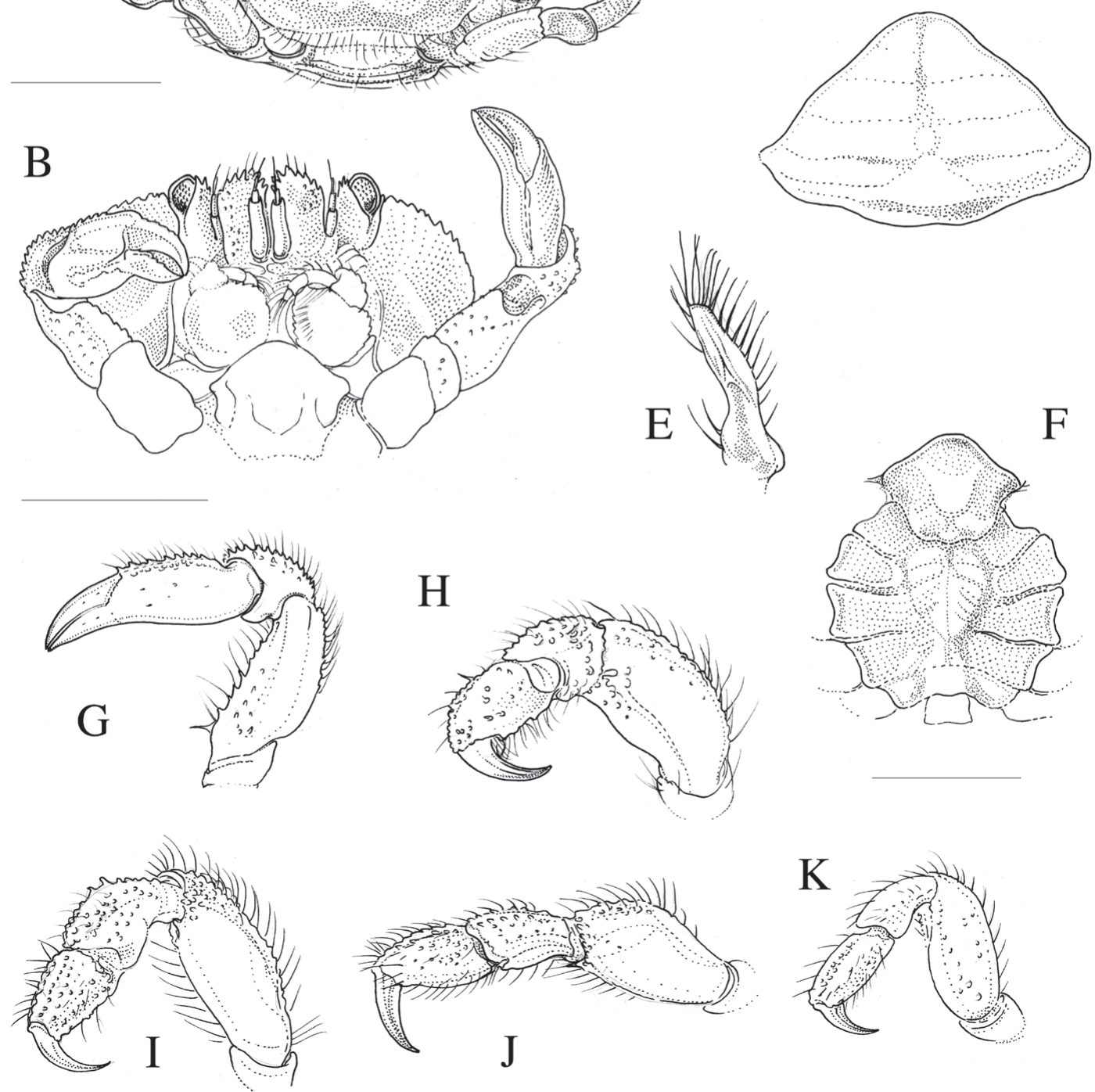

Fig. 6. Allotype Fungicola syzygia sp. nov. (RMNH.Crus.D.53224). A, habitus, dorsal view; B, anterolateral margin of carapace, ventral view; C, MXP3; D, abdomen; E, gonopod; F, thoracic sternites; G, left P1 (cheliped); H, left P2; I, left P3; J, left P4; K, left P5. Scale bars $1 \mathrm{~mm}, \mathrm{~B}, \mathrm{G}-\mathrm{K}$ as well as C-D and E-F share scale bar. 
P1 (chelipeds, Fig. 5D) slender; ischium length $1 / 2$ height; merus length twice height with scattered small tubercles and few short setae; carpus with pronounced granules on distal margin, propodus with granules on distal margin, fingers slender, mesial surfaces of fingers smooth, cutting edge entire.

$\mathrm{P} 2$ (Fig. 5E) coarser than P1; ischium without setae; merus stout, two times longer than broad, few, small conical tubercles on distal half of dorsal surface, simple short setae on lateral, dorsal surface; carpus surface granulated, with setae; propodus about as long as carpus, surface granulated, fine scattered setae, dactylus smooth, sharp, curved ventrally.

P3 (Fig. 5F) ischium without setae; merus stout and rounded, prominent distomesial projection, surface with tubercles, simple setae; carpus not extending more than at right angle; carpus bend; carpus, propodus roughly of equal length, rounded tubercles on dorsal surface, simple setae on lateral, dorsal surface; dactylus halflength of propodus, smooth, sharp, curved ventrally.

P4 (Fig. 5G) ischium without setae; merus stout and rounded, small distomesial projection, surface with tubercles and simple setae; carpus not extending more than at right angle; carpus bend; carpus, propodus roughly of equal length, rounded tubercles on dorsal surface, simple setae on lateral, dorsal surface; dactylus half-length of propodus, smooth, sharp, curved ventrally, with setae.

P5 (Fig. 5H) slender; ischium without setae; merus, carpus, propodus of equal length; merus slightly bend, very few scattered tubercles and setae, carpus, propodus with sharp tubercles on dorsal surface; dactylus $1 / 3$ length of propodus, smooth, sharp, straight, with few setae.P-5 right sampled for DNA analysis.

Abdomen (= pleon) enlarged, lateral margin fringed with setae (Fig. 5A-B).

Description allotype. Carapace (Fig. 6A) subrectangular to squaroid, slightly longer than broad, anterior half broader than posterior half, surface covered with fine granules; flat in lateral view, not deflected anteriorly; cardio-intestinal region outlined; internal orbital angle rounded; frontal margin and anterolateral borders armed with spinules, few setae; anterolateral border moderately convex; lateral borders not clearly defined, somewhat concave. Pterygostomial region fused to carapace.

Ocular peduncles (Fig. 6A-B) with small spines on distal margin, cornea round to oval, longer than broad; antennule shorter than ocular peduncles; antennal segment two longer than broad, slightly extending beyond eyestalk, distal margin with several lateral spines.
MXP3 (Fig. 6C) exopod subrectangular, reaching approx. $1 / 2$ length of ischium, with tubercles, setae; ischium subquadrangular, smooth, mesial and distal margin slightly rounded, anteromesial lobe with setae, distal margin with tubercles; merus with distolateral projection, anterolateral margin of merus with tubercles, setae; distal portion of carpus with tubercles, setae; dactylus with bundle of long setae.

P1 (chelipeds, Fig. 6G) slender; ischium length $1 / 3$ height; merus with scattered small tubercles, few simple setae; carpus, propodus with pronounced granules on distal margin, fingers slender, mesial surfaces of fingers smooth, cutting edge entire.

P2 (Fig. 6H) ischium without setae; merus stout, two times longer than broad, few, small conical tubercles on distal half of dorsal surface, simple short setae on lateral, dorsal surface; carpus surface granulated, with setae; propodus about as long as carpus, surface granulated, fine scattered setae, dactylus smooth, sharp, curved ventrally.

P3 (Fig. 6I) ischium without setae; merus surface with tubercles and setae; joint between merus, carpus not extending more than at right angle; carpus and propodus roughly of equal length, conical tubercles on spread over surface, with setae; dactylus smooth, sharp, curved ventrally.

P4 (Fig. 6J) similar to P3; ischium without setae; merus stout with distomesial projection, surface with tubercles and simple setae; joint between merus, carpus not extending more than at right angle; carpus and propodus roughly of equal length; conical tubercles on spread over surface, with setae; dactylus smooth, sharp, curved ventrally.

P5 (Fig. 6K) slender; ischium without setae; merus length twice height; carpus, propodus of equal length; merus, carpus, propodus with few scattered tubercles and setae; dactylus $1 / 2$ length of propodus, smooth, sharp, curved ventrally.

Abdomen rhomboid, longest and widest at 5th segment; telson rounded (Fig. 6D).

Gonopod slightly curved laterally, broad shoulder, apex rounded, long setae. (Fig. 6E)

Colour. An overall pale beige-grey. On some specimens a horseshoe shaped pattern is visible on the carapace, more pronounced in males than in females (Fig. 7A-E). A similar pattern can occur in specimens of $F$. fagei, hence colour pattern is not a diagnostic character.

Host corals. Fungicola syzygia can be found inhabiting flattened pits lodged between septae (see Vehof et al., 


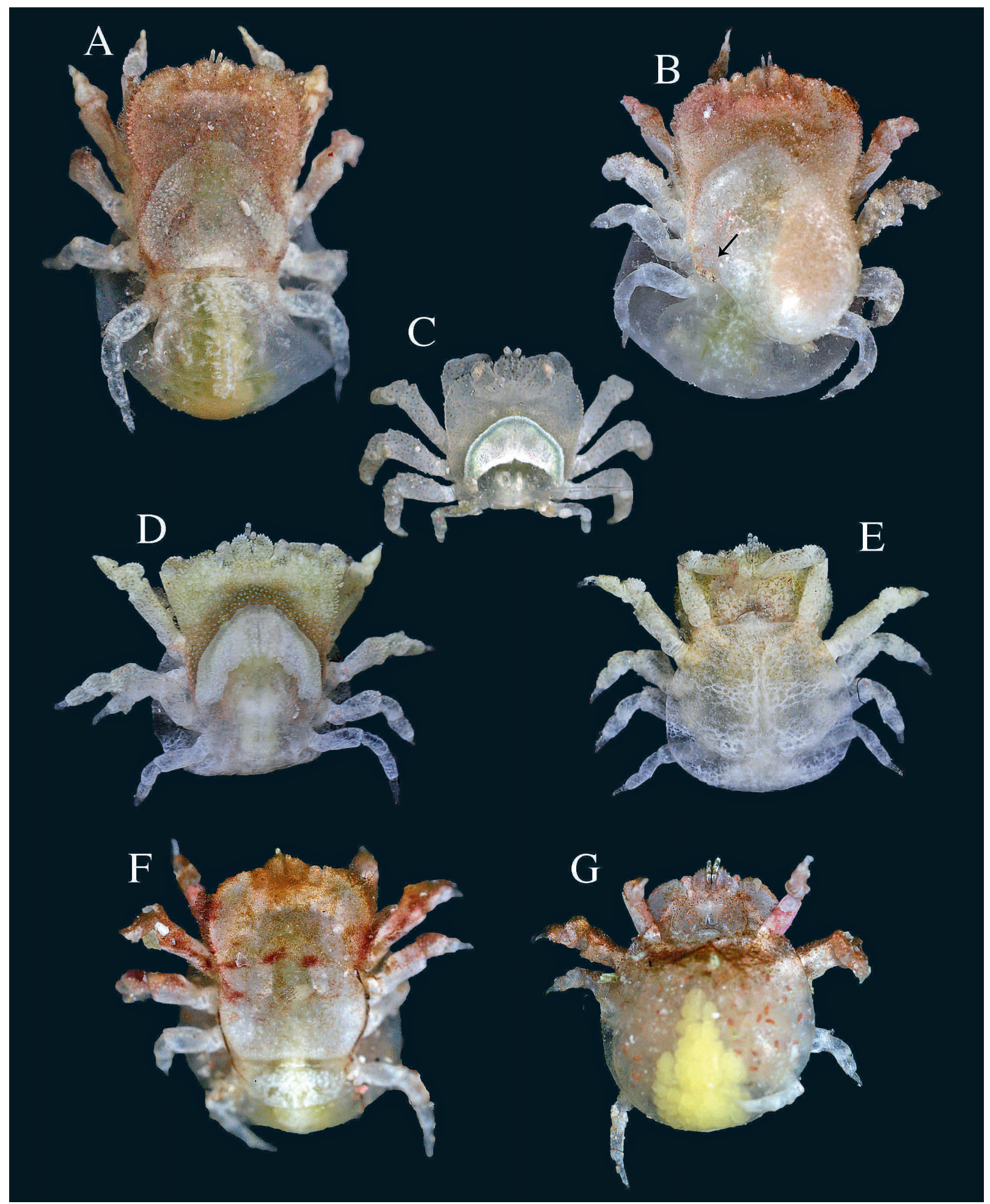

Fig. 7A-G. Fungicola syzygia sp. nov., colouration in life. A, RMNH.Crus.D.53225, ovigerous female; B, RMNH.Crus.D.56481, nonovigerous female parasitized by the isopod Carcinione platypleura Bourdon, 1983 (Isopoda: Bopyridae), male isopod indicated by arrow; C, RMNH.Crus.D.56479 male; D-E, RMNH.Crus.D.56480, non-ovigerous female. Fungicola fagei, colouration in life. F-G, RMNH.Crus.D.53234, ovigerous female. 
in press: Fig. 1A). Main host genera are Cycloseris and Pleuractis, but there are single records from other species (Fig. 2, Table S3). Fungicola syzygia sp. nov. (RMNH. Crus.D.54244) was found once in Lithophyllon repanda, the most common host of F. utinomi (Fig. 2). This is the fourth species recorded from mushroom corals.

Diagnostic characters. Fungicola fagei and F. syzygia sp. nov. can be separated based on their host specificity and DNA. For the latter, based on the results of this study, a positive identification can be achieved by analysis of a single mitochondrial marker. F. fagei and $F$. syzygia sp. nov. are more difficult to separate based on morphology. Both species show considerable intraspecific variation in the shape (angle) of the external orbital angle and the border between the orbital angles. Intraspecific variation is also observed on the lateral margins. In general, in $F$. syzygia sp. nov. the lateral margins are more concave then in F. fagei. Based on the carapace length / carapace width ration, it is clear that $F$. fagei is more rectangular than $F$. syzygia sp. nov., which is almost squaroid. The one available male of $F$. fage $i$ is somewhat of an outlier, perhaps the results of sexual dimorphism. After removal of this single male from the CL / CW (all) category the mean ratio becomes $1.10 \pm 0.08(n=9)$ (Table 3 ).

Distribution range. Fungicola syzygia is so far known from various locations in Indonesia, Malaysia and the Maldives. The male specimens of Takeda and Tamura (1979) may belong to the new species $F$. syzygia sp. nov. (see remarks), which would add Japan to the known distribution range if the identification were confirmed. The figured specimen in $\mathrm{Ng}$ et al. (2008) was collected in Vanuatu (see remarks). The distribution of F. syzygia sp. nov. possibly overlaps the distribution of their host corals (for fungiid distributions see Hoeksema (1989)), but large areas of their host's distribution have not yet been examined for gall crabs.
Remarks. A sibling species is a cryptic sister species; two species that are the closest relative of each other and have not been distinguished from one another taxonomically (Bickford et al., 2007). Fungicola syzygia sp. nov. is therefore a sibling species of $F$. fagei. It is the third species assigned to the genus Fungicola.

Previous workers most likely did not encounter this new species in their material. Fize and Serène (1957) collected $F$. fage $i$ specimens from $S$. dentata (and possibly $S$. robusta; see host corals section of $F$. fagei), and did not collect gall crabs from Cycloseris or Pleuractis. Their material therefore most likely consists of solely $F$. fagei. Specimens of $F$. fagei were furthermore collected during the Rumphius I and II expeditions to Indonesia. Kropp (1994) re-examined the Rumphius material, but mentioned that the specimens of $F$. fage $i$ were no longer available and that the host corals were not included. Takeda and Tamura (1979) did collect two male specimens, which, based on the host specificity data (Fungia paumotensis [=Pleuractis paumotensis]) and the illustrations, possibly could be identified as Fungicola syzygia (National Museum of Nature and Science Tokyo, NSMTCr. 5896/7). Ng et al. (2008: Fig. 156) illustrated a specimen of Fungicola sp., collected from P. paumotensis (B.W. Hoeksema, pers. comm.) in Santo, Vanuatu. Pleuractis paumotensis is only known to host Fungicola syzygia, therefore this material is tentatively included in the synonymy of this species.

Etymology. Syzygia in reference to the type locality Ternate, once the world's major producer of cloves (Syzygium aromaticum L. Merr. and Perry). The Latin

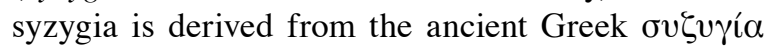
[suzugia], for a pair of related things or union, referring to the obligate symbiosis between the gall crab and its host coral.
Table 3. Characters distinguishing Fungicola fage $i$ and $F$. syzygia sp. nov.

\begin{tabular}{|c|c|c|}
\hline & $F$ fagei & F. syzygia sp. nov. \\
\hline $\begin{array}{l}\text { host genus } \\
\text { carapace shape }\end{array}$ & $\begin{array}{l}\text { Podabacia, Sandalolitha } \\
\text { subrectangular }\end{array}$ & $\begin{array}{l}\text { Cycloseris, Pleuractis } \\
\text { subrectangular to squaroid }\end{array}$ \\
\hline CL / CW (all) & $1.12 \pm 0.10(\mathrm{n}=10)$ & $1.02 \pm 0.07(n=20)$ \\
\hline CL / CW (ovig. f) & $1.13 \pm 0.06(\mathrm{n}=7)$ & $1.02 \pm 0.08(\mathrm{n}=11)$ \\
\hline CL / CW (m) & $1.33(\mathrm{n}=1)$ & $1.02 \pm 0.03(\mathrm{n}=5)$ \\
\hline border between orbital angles (f) & (mildly) undulating & straight to mildly undulating \\
\hline lateral margin carapace & $\begin{array}{l}\text { somewhat defined, less } \\
\text { concave than } F \text {. syzygia } \\
\text { sp. nov. }\end{array}$ & $\begin{array}{l}\text { not well-defined, more } \\
\text { concave than } F \text {. fagei }\end{array}$ \\
\hline merus MXP3 & $\begin{array}{l}\text { modest distolateral } \\
\text { projection }\end{array}$ & $\begin{array}{l}\text { pronounced distolateral } \\
\text { projection }\end{array}$ \\
\hline
\end{tabular}




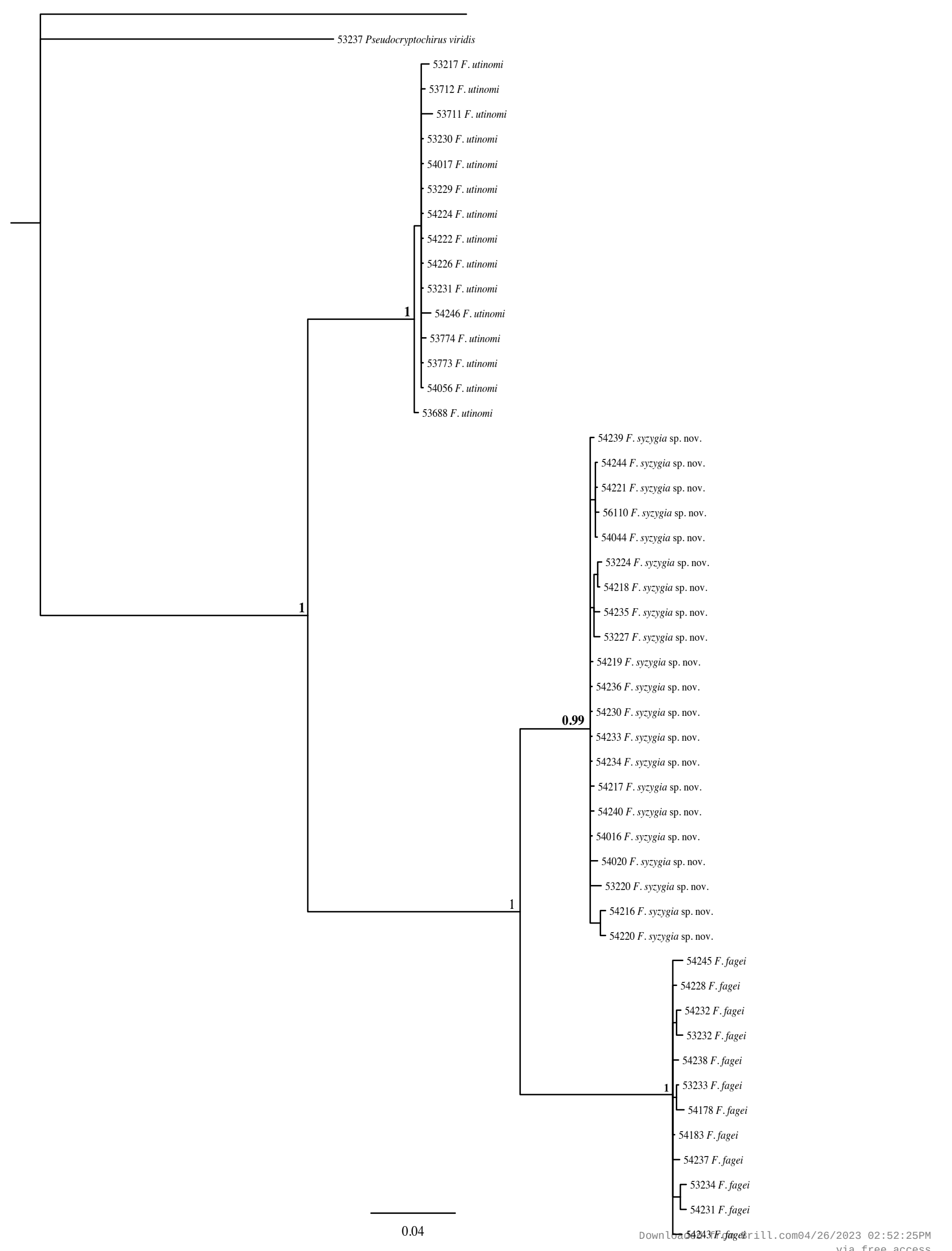




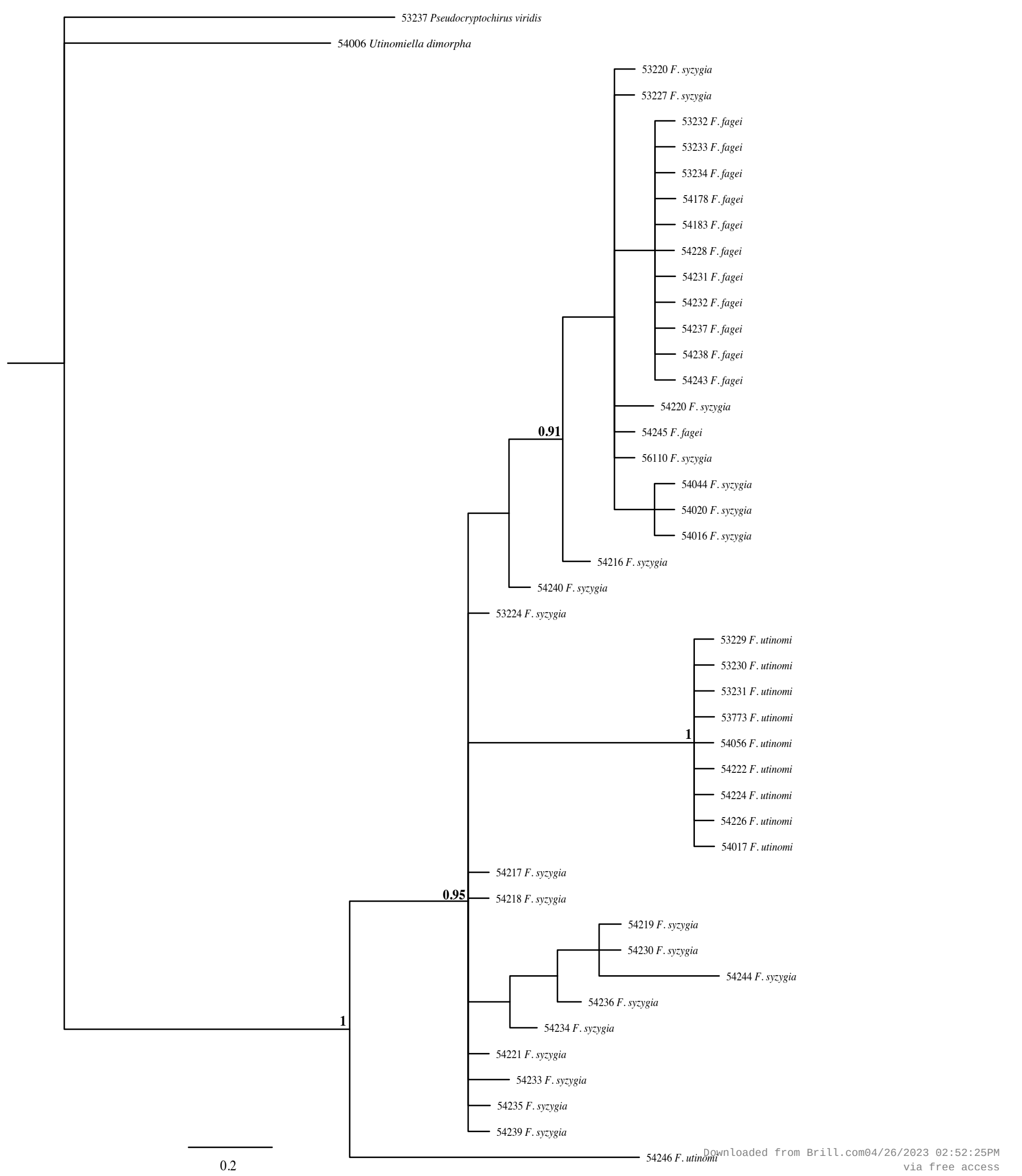

